\title{
EVALUATION OF THE USEFULNESS OF SPIDER WEBS AS AN AIR QUALITY MONITORING TOOL FOR HEAVY METALS
}

\author{
OCENA EFEKTYWNOŚCI SIECI PAJĘCZYCH W MONITOROWANIU \\ JAKOŚCI POWIETRZA ATMOSFERYCZNEGO
}

\begin{abstract}
The study aims at evaluating whether webs reflect the level of air pollution measured with conventional methods. Webs of species Malthonica silvestris (1. KOCH, 1872) (Araneae: Agelenidae) were sampled. Samples were analyzed for heavy metals $(\mathrm{Pb}, \mathrm{Zn})$ content. According webs analyses and classic measurements three traffic -oriented sites in Wroclaw (South-West Poland) showed significantly higher mean concentrations of heavy metals than two other sites situated in quieter, low traffic areas. A very strong significant positive correlation was revealed among average concentrations of $\mathrm{Zn}$ and $\mathrm{Pb}$ associated with fine particulate matter of atmospheric aerosol $\left(\mathrm{PM}_{1}\right)$ and webs. We also observed a very strong significant positive correlation among $\mathrm{Zn}$ and $\mathrm{Pb}$ concentrations on webs and $\mathrm{PM}_{2.5}$. Any significant correlation among PM-emission fractions 2.5 and 10 and associated heavy metals and dust deposited on spider webs was not observed. Although spider webs proved useful indicators of environmental pollution the obtained results suggest that this tool should be used to evaluate the emission of heavy metals in the similar way as other bioindicators such as mosses and lichens are commonly used. The measured concentrations on webs do not reflect results obtained with classic methods. We conclude that spider webs are good for bioindication of road traffic emissions, they could be even more reliable compared to use of some other bioindicators whose activity is often limited by the lack of water and sun.
\end{abstract}

Keywords: spider webs, indication, heavy metals, vehicle emissions, airborne particles

\section{Introduction}

The combustion products cause the development of many serious human diseases in a long-term exposition. What is more, heavy metals present in combustion products

\footnotetext{
${ }^{1}$ Biology and Ecology Team, Department of Environmental Protection, Wroclaw University of Technology, ul. Wybrzeże Wyspiańskiego 27, 50-370 Wrocław, Poland, phone +48 $71 \quad 320 \quad 22$ 37, email: justyna.rybak@pwr.wroc.pl

${ }^{2}$ Ecologistics Team, Department of Environmental Protection, Wroclaw University of Technology, ul. Wybrzeże Wyspiańskiego 27, 50-370 Wrocław, Poland, phone +48 $71 \quad 320 \quad 20$ 25, email: izabela.sowka@pwr.wroc.pl

${ }^{3}$ Crocker Nuclear Laboratory, University of California at Davis, Davis, CA 95616, email: ktrzeplanabaglo@ucdavis.edu

*Corresponding author: justyna.rybak@pwr.wroc.pl
} 
constitute one of the most important group polluting the environment and affecting the human health. Typically mosses, lichens or plant leafs are used for estimating ambient air pollution caused by traffic [1-3]. As spider webs capture airborne particulates it has been proved that they could be a useful and original indicator of the environment pollution [4-7]. The advantages of the use of spider webs are as follows: low cost and easy sampling method, universal availability (webs of Agelenidae are abundant in low vegetation and bushes but some species inhabit the hollows of tree trunks, caves, and houses, some indoor species are cosmopolitan in distribution) [8], a secluded location preventing webs from the severe weather conditions, non-invasiveness of studies [4-7]. The research conducted by Hose et al [4] demonstrated that heavy metals do not enter the web matrix, as they are collected on web surfaces. A dense network of the silk alone (in the studied species belonging to Cribellate, without sticky glue in the web threads) is very effective in trapping airborne particles.

Moreover, further studies proved that older webs accumulate more airborne particulates then younger ones, enabling the long-term assessment of the air pollution level in a selected place (under the condition that age of web is already known), in contrast to the classic measurements often providing information about the temporary state of environment (24-48 hours) [4-7]. As the conventional methods are expensive and are often conducted under the supervision they are rarely used for long-term studies of the air quality.

In order to assess the credibility of the use of spiders as a pollution indicators the airborne particulate matter ( $\mathrm{PM})$ and associated heavy metals $(\mathrm{Pb}, \mathrm{Zn})$ in the roadside environment were analyzed at five sites with the use of classic method of air pollution assessment (impactors) and spider webs. Our hypothesis was that the content of heavy metals on spider webs would differ among sites and would be correlated with the airborne particulate matter and associated trace elements $\mathrm{Zn}, \mathrm{Pb}$ measured with the classic method.

\section{Materials and methods}

\section{Spider and the web description}

Species of Malthonica silvestris (1. KOCH, 1872) from Agelenidae family was chosen for studies because it does not consume its own web [6]. A new webs collected after 30 days from the creation of the construction were only used for chemical analyses (collected after the removal an old one). To facilitate the research the frames with defined dimensions were fixed in selected sites enabling settling them by spiders, additionally specimens were also moved to the laboratory in order to weave the web inside the frame and then such items were transferred to the sites $[6,9]$. Webs of similar sizes, age and weight were used for analyses [4].

Studies of Hose et al [4] proved that the majority of pollutants depositing on the webs are not built into matrix in Cribellate spiders (Agelenidae belong to Cribellate). Although, such examinations were not conducted for Agelenidae representatives we could presume that this is also the case for all spiders producing a dry silk (like M. silvestris). Spiders from the Agelenidae family feed mainly on insects and other non-flying invertebrates (beetles, springtails, ants, even earthworms) which, unlike flying insects, do not overcome long distances. In case of predating on flying insects silk produced by spiders could include pollutants coming from the larger area than studied one, which derives from the higher activity of flying insects and bigger distances they usually overcome [6, 10-12]. 


\section{Analytical procedures}

The silk was collected only into clean glass phials with glass sterile baguettes and was frozen for chemical analyses [4-6]. Samples were defrosted, dried for $48 \mathrm{~h}\left(70^{\circ} \mathrm{C}\right)$ and weighed (accuracy of $0.0001 \mathrm{~g}$ ). The metals content was determined with method ICP-OES using the sequential selected emission spectrometer ARL 3410, applying the method of the absolute calibration towards standards of $\mathrm{Pd}$ and $\mathrm{Zn}$ and for the range of concentrations $0-10 \mathrm{mg} / \mathrm{dm}^{3}\left(0-10 \mu \mathrm{g} / \mathrm{cm}^{3}\right)$ in the examined solutions. The web samples were prepared according to the following procedure: a dry residue after triple extraction was digested with the use of nitro-hydrochloric acid (solution of concentrated nitric and hydrochloric acids, $3 / 1 \mathrm{v} / \mathrm{v}$ ) during 24 hours, applying triple sequences of the digestion by adding $2 \mathrm{~cm}^{3}$ of freshly prepared 'aqua regia' (or $1.5 \mathrm{~cm}^{3} \mathrm{HCl}+0.5 \mathrm{~cm}^{3} \mathrm{HNO}_{3}$ ) to sample, a mixture was left for 1 hour in the room temperature, next slowly increased to upheaval (3 hours) and kept boiled during 4 hour using heating block. The sample after digestion was concentrated to the minimal volume (about $0.5 \mathrm{~cm}^{2}$ ), and dissolved in the water (distilled water or $1 \%$ solution of hydrochloric acid), filtered from insoluble mineral elements $\left(e g \mathrm{SiO}_{2}\right)$, diluted in the measuring small flask to the defined volume $\left(10 \mathrm{~cm}^{2}\right.$ - the minimal required volume needed for qualitative and quantitative analyses) and analyzed with ICP method. Analyses were performed in a Chemical Laboratory of Elemental Analyses in the Chemical Department of the Wroclaw University [5-6].

The collection of size fractioned airborne particulate matter $\left(\mathrm{PM}_{1}, \mathrm{PM}_{2.5}, \mathrm{PM}_{10}\right)$ was done at five sites during the period of two years from May to July 2011 and 2012. $\mathrm{PM}_{1}$ and $\mathrm{PM}_{10}$ were collected using cascade impactors of Harvard type (MS\&T Area Samplers, Air Diagnostics and Engineering, Inc., Harrison, USA). The air flow extorted ultra-quiet non-oil vacuum pumps (Air Diagnostics and Engineering, air sampling pump, model SP-280E). The collection of $\mathrm{PM}_{2.5}$ was done with the impactor applied in the United States in the Interstate Program of the Monitoring of the Visibility in the IMPROVE Atmosphere (Interagency Monitoring of Protected Visual Environment). $\mathrm{PM}_{2.5}$ was collected on Teflon filters (Whatman, $2 \mu \mathrm{m}$ PTFE $46.2 \mathrm{~mm}$, air flow $22.8 \mathrm{dm}^{3} / \mathrm{min}$ ). Teflon membranes (Anderson Membrane Filters Teflon, of $37 \mathrm{~mm}$ diameter) were applied for $\mathrm{PM}_{1}$ and $\mathrm{PM}_{10}$. The filters were weighed before and after the samples collection in order to determine the mass collected in the individual fractions (PN-EN 14907: 2006). The flow rate for $\mathrm{PM}_{1}$ and $\mathrm{PM}_{2.5}$ was $23 \mathrm{dm}^{3} / \mathrm{min}$, however, in case of particles $\mathrm{PM}_{10}$ the flow of $10 \mathrm{dm}^{3} / \mathrm{min}$ was applied. The air flow was controlled by the flow-meter of Ataris type. The time of the conscription was 24 hours (PN-EN 123441: 2006, Regulation of the Environment Minister, 2008). The chemical analyses were conducted as a part of the cooperation with Crocker Nuclear Laboratory, University of California at Davis (UCD) specializing in determining the morphology, fractional disintegration and chemical composition of individual particles, particularly particles of aerosols. The analyses included quantitative analysis of dusts of individual fractions were done with the method of fluorescent spectrometry X-ray (EDXRF). The chemical composition of the collected dust samples was analyzed with XRF Epsilon-5 spectrometer (PANalytical, Amelo, Netherlands). The analyses were performed in each sample of the selected airborne particulate matter in order to measure the heavy metals content $(\mathrm{Pb}, \mathrm{Zn})$.

The concentration of heavy metals were measured using external calibration of a multi-element standard solution $\left(r^{2}>0.999\right)$. The analyses were carried out in triplicate 
and the average values were reported. Instrument precision were determined by introducing the same quantity of one sample 20 times, and then the relative standard deviation was calculated $(\mathrm{RSD}<5 \%)$.

\section{Sampling sites}

The researches were conducted in 2011 and 2012 in 5 sites in Wroclaw. While choosing the sampling sites we took into consideration if the area was highly exposed to the vehicle pollution. Three sites were located in the vicinity of main communication hubs in the city of Wroclaw, South-West of Poland (sites 3, 4 and 5), remaining two sites (site 1 and 2) were situated in the quieter, low traffic areas (Fig. 1). A detailed description of sampling sites is presented in Table 1. All sites were protected from the rain what secured webs before the accidental pollutants washing.

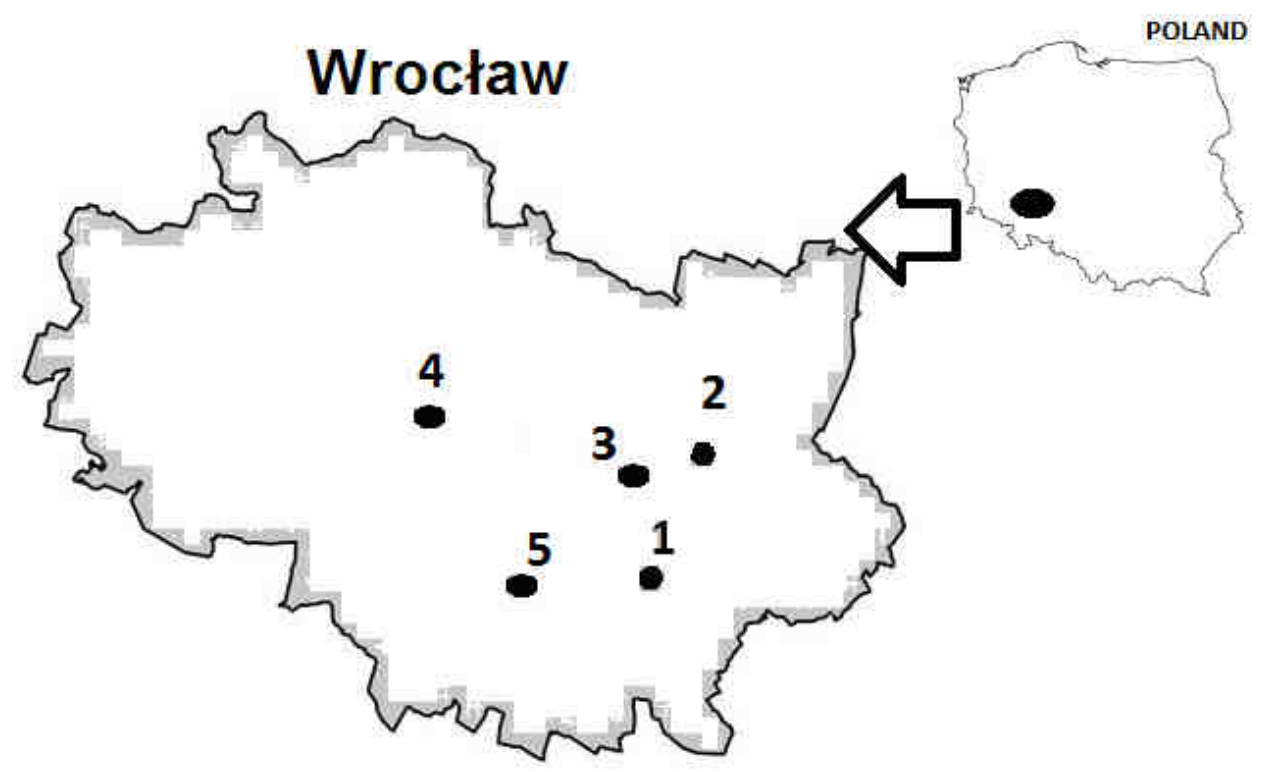

Fig. 1. The map of sites selected for studies

Description of sampling sites

\begin{tabular}{|c|c|c|c|}
\hline Site & $\begin{array}{c}\text { Coordinates for sampling } \\
\text { location }\end{array}$ & Description & $\begin{array}{l}\text { Selected meteorological } \\
\text { conditions }\end{array}$ \\
\hline $\begin{array}{c}\text { Site } \\
1\end{array}$ & $\begin{array}{l}\text { N51 }{ }^{\circ} 6 \text { '9.0896"/ } \\
\text { E17 } 3 \text { '55.0319" }\end{array}$ & $\begin{array}{l}\text { A hydrotechnical building. } \\
\text { Meadows, partly with bushes } \\
\text { and trees surrounded by the } \\
\text { system of ditches and channels. } \\
\text { A drinking water is delivered } \\
\text { for the city of Wroclaw from } \\
\text { this area, which lays in distance } \\
\text { from main communication hubs }\end{array}$ & $\begin{array}{l}\text { Maximum daily temperature: } \\
21.6^{\circ} \mathrm{C} \text {. Minimum daily } \\
\text { temperature: } 14.4^{\circ} \mathrm{C} \text {. The } \\
\text { average wind speed: } 3.7 \mathrm{~m} / \mathrm{s}\end{array}$ \\
\hline
\end{tabular}




\begin{tabular}{|c|c|c|c|}
\hline $\begin{array}{l}\text { Site } \\
2\end{array}$ & $\begin{array}{l}\text { N51 }{ }^{\circ} 6{ }^{\prime} 3.4628 " / \\
\text { E17 } 57^{\prime} 40.8611^{\prime \prime}\end{array}$ & $\begin{array}{l}\text { The housing estate called } \\
\text { Biskupin in the eastern district } \\
\text { of Wroclaw. A diversified area } \\
\text { including the allotments, park, } \\
\text { high and low buildings from } \\
\text { low to moderate traffic intensity }\end{array}$ & $\begin{array}{c}\text { Maximum daily temperature: } \\
21^{\circ} \mathrm{C} \text {. Minimum daily } \\
\text { temperature: } 13.4^{\circ} \mathrm{C} \text {. The } \\
\text { average wind speed: } 2.8 \mathrm{~m} / \mathrm{s}\end{array}$ \\
\hline $\begin{array}{c}\text { Site } \\
3\end{array}$ & $\begin{array}{l}\text { N51ㅇ 6' 39.4637"/ } \\
\text { E17 } 3^{\circ} 29.0381 "\end{array}$ & $\begin{array}{l}\text { The Grunwaldzki square, } \\
\text { a main interchange with heavy } \\
\text { motor traffic } 24 / 7\end{array}$ & $\begin{array}{c}\text { Maximum daily temperature: } \\
20^{\circ} \mathrm{C} \text {. Minimum daily } \\
\text { temperature: } 12.4^{\circ} \mathrm{C} \text {. The } \\
\text { average wind speed: } 1.8 \mathrm{~m} / \mathrm{s}\end{array}$ \\
\hline $\begin{array}{c}\text { Site } \\
4\end{array}$ & $\begin{array}{l}\text { N51ํㄱ' } 21.348^{\prime \prime /} \\
\text { E17 }\end{array}$ & $\begin{array}{c}\text { One of main and very important } \\
\text { communication hubs in the city } \\
\text { of Wroclaw (Dluga street) }\end{array}$ & $\begin{array}{c}\text { Maximum daily temperature: } \\
21.2^{\circ} \mathrm{C} \text {. Minimum daily } \\
\text { temperature: } 13.3^{\circ} \mathrm{C} \text {. The } \\
\text { average wind speed: } 1.9 \mathrm{~m} / \mathrm{s}\end{array}$ \\
\hline $\begin{array}{l}\text { Site } \\
5\end{array}$ & $\begin{array}{c}\mathrm{N} 51^{\circ} 5^{\prime} 11.0663 " / \\
\mathrm{E} 17^{\circ} 0 \text { 0' } 44.6938^{\prime \prime}\end{array}$ & $\begin{array}{c}\text { One of the main street } \\
\text { (Wisniowa street) for transport } \\
\text { system in the city, characterized } \\
\text { by one of the highest levels of } \\
\text { the combustion gases in the city } \\
\text { [13] }\end{array}$ & $\begin{array}{c}\text { Maximum daily temperature: } \\
21.3^{\circ} \mathrm{C} \text {. Minimum daily } \\
\text { temperature: } 14.2^{\circ} \mathrm{C} \text {. The } \\
\text { average wind speed: } 1.3 \mathrm{~m} / \mathrm{s}\end{array}$ \\
\hline
\end{tabular}

\section{Statistics}

The STATISTICA® package was used for all calculations. Data were checked for the normal distribution (Shapiro-Wilk W test) and homogeneity of variance (Levene's test). The tests of significance were made at $95 \%$ confidence level. A statistical analysis included a determination of Pearson correlation coefficient between measured values of concentrations of zinc and lead in dust $\left(\mathrm{PM}_{1} ; \mathrm{PM}_{2.5} ; \mathrm{PM}_{10}\right)$ and spider webs of $M$. silvestris and the one-way ANOVA variance analysis to verify if the defined factors influence on averages values of studied features. In case of obtaining the positive results additionally the scale of this influence was determined. A homogeneity of examined groups was also checked concerning the location of research sites (one-way ANOVA).

\section{Results}

The concentration of $\mathrm{PM}$ mass and associated $\mathrm{Pb}$ and $\mathrm{Zn}$ measured with classic method and with the webs of $M$. silvestris are presented in Tables 2 and 3.

Table 2

Mean concentrations and standard deviation (SD) of heavy metals at selected sites in 2011-2012, the samples were collected after 30 days of exposure for Malthonica sylvestris. Concentrations are given in $\mu \mathrm{g} / \mathrm{g}$ dry weight $(n=7)$. The content of two metals on webs differed significantly among sampling sites $(p<0.05)$

\begin{tabular}{|c|c|c|c|c|c|}
\hline $\begin{array}{c}\text { Heavy metal } \\
{[\boldsymbol{\mu g} / \mathbf{g}]}\end{array}$ & $\begin{array}{c}\text { site } \\
\text { No. 1 }\end{array}$ & $\begin{array}{c}\text { site } \\
\text { No. 2 }\end{array}$ & $\begin{array}{c}\text { site } \\
\text { No. 3 }\end{array}$ & $\begin{array}{c}\text { site } \\
\text { No. . }\end{array}$ & $\begin{array}{c}\text { site } \\
\text { No. 5 }\end{array}$ \\
\hline \multirow{2}{*}{$\mathrm{Pb} / 2011$} & 131 & 87 & 670 & 523 & 2280 \\
& \pm 19 & \pm 6 & \pm 40 & \pm 48 & \pm 570 \\
\hline \multirow{2}{*}{$\mathrm{Pb} / 2012$} & 71 & 262 & 1398 & 660 & 1558 \\
& \pm 11 & \pm 28 & \pm 57 & \pm 50 & \pm 30 \\
\hline \multirow{2}{*}{$\mathrm{Zn} / 2011$} & 71 & 407 & 8704 & 1088 & 8062 \\
& \pm 8 & \pm 22 & \pm 293 & \pm 72 & \pm 80 \\
\hline \multirow{2}{*}{$\mathrm{Zn} / 2012$} & 85 & 213 & 2113 & 711 & 6475 \\
& \pm 21 & \pm 57 & \pm 91 & \pm 205 & \pm 236 \\
\hline
\end{tabular}


Table 3

Mean concentrations and standard deviation (SD) of heavy metals at selected sites in 2011-2012, the samples of dust collected at 5 sites. Concentrations are given in $\mu \mathrm{g} / \mathrm{m}^{3}(n=8)$. The content of metals associated with particulate matter differed significantly among sampling sites $(p<0.05)$

\begin{tabular}{|c|c|c|c|c|c|}
\hline Fraction/metal/year & site No. 1 & site No. 2 & $\begin{array}{c}\text { site } \\
\text { No. } 3\end{array}$ & site No. 4 & $\begin{array}{c}\text { Site } \\
\text { No. } 5\end{array}$ \\
\hline $\mathrm{PM}_{1} \mathrm{~Pb} / 2011$ & $\begin{array}{c}4.8 \\
\pm 3.6 \\
\end{array}$ & $\begin{array}{c}8.2 \\
\pm 5.8 \\
\end{array}$ & $\begin{array}{l}14.2 \\
\pm 2.6 \\
\end{array}$ & $\begin{array}{r}10.2 \\
\pm 6.8 \\
\end{array}$ & $\begin{array}{r}16.3 \\
\pm 4.2 \\
\end{array}$ \\
\hline $\mathrm{PM}_{2.5} \mathrm{~Pb} / 2011$ & $\begin{array}{r}6.3 \\
\pm 3.3 \\
\end{array}$ & $\begin{array}{r}12.1 \\
\pm 7.1 \\
\end{array}$ & $\begin{array}{r}22.5 \\
\pm 3.7 \\
\end{array}$ & $\begin{array}{r}18.7 \\
\pm 8.3 \\
\end{array}$ & $\begin{array}{r}20.9 \\
\pm 1.8 \\
\end{array}$ \\
\hline $\mathrm{PM}_{10} \mathrm{~Pb} / 2011$ & $\begin{array}{r}10.3 \\
\pm 2.8 \\
\end{array}$ & $\begin{array}{r}14.8 \\
\pm 8.2 \\
\end{array}$ & $\begin{array}{c}29.1 \\
\pm 10.9\end{array}$ & $\begin{array}{l}24.6 \\
\pm 6.9 \\
\end{array}$ & $\begin{array}{l}44.8 \\
\pm 8.6 \\
\end{array}$ \\
\hline $\mathrm{PM}_{1} \mathrm{~Pb} / 2012$ & $\begin{array}{c}1.5 \\
\pm 0.7\end{array}$ & $\begin{array}{c}3.8 \\
\pm 2.7 \\
\end{array}$ & $\begin{array}{c}9.6 \\
\pm 5.4 \\
\end{array}$ & $\begin{array}{c}4.2 \\
\pm 2.9 \\
\end{array}$ & $\begin{array}{c}9.2 \\
\pm 1.5\end{array}$ \\
\hline $\mathrm{PM}_{2.5} \mathrm{~Pb} / 2012$ & $\begin{array}{c}7.1 \\
\pm 5.1 \\
\end{array}$ & $\begin{array}{c}6.7 \\
\pm 2.2 \\
\end{array}$ & $\begin{array}{c}9.7 \\
\pm 6.7 \\
\end{array}$ & $\begin{array}{c}6.5 \\
\pm 3.5 \\
\end{array}$ & $\begin{array}{r}18.5 \\
\pm 5.3\end{array}$ \\
\hline $\mathrm{PM}_{10} \mathrm{~Pb} / 2012$ & $\begin{array}{r}13.5 \\
\pm 4.8\end{array}$ & $\begin{array}{r}17.4 \\
\pm 4.7 \\
\end{array}$ & $\begin{array}{c}23.1 \\
\pm 12.6\end{array}$ & $\begin{array}{r}15.6 \\
\pm 3.9\end{array}$ & $\begin{array}{r}33.2 \\
\pm 9.6\end{array}$ \\
\hline $\mathrm{PM}_{1} \mathrm{Zn} / 2011$ & $\begin{array}{c}7.5 \\
\pm 2.5 \\
\end{array}$ & $\begin{array}{r}18.3 \\
\pm 8.4 \\
\end{array}$ & $\begin{array}{l}10.8 \\
\pm 0.8 \\
\end{array}$ & $\begin{array}{c}9.9 \\
\pm 2.4 \\
\end{array}$ & $\begin{array}{r}14.7 \\
\pm 3.0 \\
\end{array}$ \\
\hline $\mathrm{PM}_{2.5} \mathrm{Zn} / 2011$ & $\begin{array}{c}16.3 \\
\pm 12.5 \\
\end{array}$ & $\begin{array}{c}27.8 \\
\pm 12.5 \\
\end{array}$ & $\begin{array}{l}32.5 \\
\pm 6.5\end{array}$ & $\begin{array}{c}32.5 \\
\pm 14.9\end{array}$ & $\begin{array}{c}76.6 \\
\pm 29.3\end{array}$ \\
\hline $\mathrm{PM}_{10} \mathrm{Zn} / 2011$ & $\begin{array}{r}18.1 \\
\pm 5.4 \\
\end{array}$ & $\begin{array}{c}42.1 \\
\pm 15.6\end{array}$ & $\begin{array}{c}63.3 \\
\pm 24.1 \\
\end{array}$ & $\begin{array}{c}58.1 \\
\pm 17.3 \\
\end{array}$ & $\begin{array}{r}107.0 \\
\pm 37.6 \\
\end{array}$ \\
\hline $\mathrm{PM}_{1} \mathrm{Zn} / 2012$ & $\begin{array}{r}9.9 \\
\pm 4.3 \\
\end{array}$ & $\begin{array}{c}6.9 \\
\pm 5.2 \\
\end{array}$ & $\begin{array}{r}21.1 \\
\pm 3.8 \\
\end{array}$ & $\begin{array}{r}9.6 \\
\pm 3.2 \\
\end{array}$ & $\begin{array}{r}31.9 \\
\pm 9.8 \\
\end{array}$ \\
\hline $\mathrm{PM}_{2.5} \mathrm{Zn} / 2012$ & $\begin{array}{r}13.9 \\
\pm 3.2 \\
\end{array}$ & $\begin{array}{l}14.1 \\
\pm 6.9 \\
\end{array}$ & $\begin{array}{c}34.4 \\
\pm 10.4 \\
\end{array}$ & $\begin{array}{l}16.7 \\
\pm 7.2 \\
\end{array}$ & $\begin{array}{r}93.3 \\
\pm 15.5 \\
\end{array}$ \\
\hline $\mathrm{PM}_{10} \mathrm{Zn} / 2012$ & $\begin{array}{c}29.8 \\
\pm 11.9 \\
\end{array}$ & $\begin{array}{c}32.4 \\
\pm 15.4 \\
\end{array}$ & $\begin{array}{c}46.4 \\
\pm 16.2 \\
\end{array}$ & $\begin{array}{c}38.4 \\
\pm 11.1 \\
\end{array}$ & $\begin{array}{r}139.0 \\
\pm 19.3 \\
\end{array}$ \\
\hline
\end{tabular}

The level of the interdependence among variables was expressed with the linear Pearson correlation coefficient. The analysis of correlation coefficients was performed for periods when samples were taken (2011 and 2012 separately) for both webs and samples measured with classic method. Results are presented in Tables 4 and 5.

Table 4

Correlation matrix for heavy metals in $\mathrm{PM} 1, \mathrm{PM}_{2.5}, \mathrm{PM}_{10}$, fractions of particulate matter and spider webs of M. silvestris in samples collected in 2011. Bold means the statistically significant values $(p<.050)$

\begin{tabular}{|c|c|c|c|c|c|c|c|c|c|c|c|}
\hline & $\begin{array}{c}\mathbf{P M}_{\mathbf{1}} \\
\mathbf{P b}\end{array}$ & $\begin{array}{c}\mathbf{P M}_{\mathbf{2 . 5}} \\
\mathbf{P b}\end{array}$ & $\mathbf{P M}_{\mathbf{1 0}} \mathbf{P b}$ & $\mathbf{P M}_{\mathbf{1}} \mathbf{Z n}$ & $\begin{array}{c}\mathbf{P M}_{\mathbf{2 . 5}} \\
\mathbf{Z n}\end{array}$ & $\begin{array}{c}\mathbf{P M}_{\mathbf{1 0}} \\
\mathbf{Z n}\end{array}$ & $\mathbf{P M}_{\mathbf{1}}$ & $\mathbf{P M}_{\mathbf{2 . 5}}$ & $\mathbf{P M}_{\mathbf{1 0}}$ & $\begin{array}{c}\text { Pb } \\
\text { webs }\end{array}$ & $\begin{array}{c}\mathbf{Z n} \\
\text { webs }\end{array}$ \\
\hline $\mathrm{PM}_{1} \mathrm{~Pb}$ & 1 & $\mathbf{0 . 9 5}$ & $\mathbf{0 . 9 5}$ & 0.3 & 0.8 & $\mathbf{0 . 9 4}$ & $\mathbf{0 . 9 2}$ & $\mathbf{0 . 9 5}$ & 0.7 & $\mathbf{0 . 9}$ & $\mathbf{0 . 9 7}$ \\
\hline $\mathrm{PM}_{2.5} \mathrm{~Pb}$ & $\mathbf{0 . 9 5}$ & 1 & 0.85 & 0.17 & 0.64 & 0.85 & $\mathbf{0 . 9 7}$ & 0.85 & 0.44 & 0.85 & 0.83 \\
\hline $\mathrm{PM}_{10} \mathrm{~Pb}$ & $\mathbf{0 . 9 5}$ & 0.85 & 1 & 0.22 & $\mathbf{0 . 9 3}$ & $\mathbf{0 . 9 8}$ & 0.85 & $\mathbf{0 . 9 6}$ & 0.84 & 0.82 & 0.8 \\
\hline $\mathrm{PM}_{1} \mathrm{Zn}$ & 0.3 & 0.17 & 0.22 & 1 & 0.4 & 0.37 & -0.01 & 0.04 & 0.08 & 0.005 & 0.1 \\
\hline $\mathrm{PM}_{2.5} \mathrm{Zn}$ & 0.8 & 0.64 & $\mathbf{0 . 9 3}$ & 0.4 & 1 & $\mathbf{0 . 9 4}$ & 0.61 & 0.82 & $\mathbf{0 . 9 1}$ & 0.61 & 0.7 \\
\hline $\mathrm{PM}_{10} \mathrm{Zn}$ & $\mathbf{0 . 9 4}$ & 0.85 & $\mathbf{0 . 9 8}$ & 0.37 & $\mathbf{0 . 9 4}$ & 1 & 0.81 & $\mathbf{0 . 9}$ & 0.78 & 0.74 & 0.8 \\
\hline $\mathrm{PM}_{1}$ & $\mathbf{0 . 9 2}$ & $\mathbf{0 . 9 7}$ & 0.85 & -0.01 & 0.61 & 0.81 & 1 & $\mathbf{0 . 9}$ & 0.5 & $\mathbf{0 . 9}$ & 0.87 \\
\hline $\mathrm{PM}_{2.5}$ & $\mathbf{0 . 9 5}$ & 0.85 & $\mathbf{0 . 9 6}$ & 0.04 & 0.82 & $\mathbf{0 . 9}$ & $\mathbf{0 . 9}$ & 1 & 0.81 & $\mathbf{0 . 9 3}$ & $\mathbf{0 . 9 5}$ \\
\hline $\mathrm{PM}_{10}$ & 0.7 & 0.44 & 0.84 & 0.08 & $\mathbf{0 . 9 1}$ & 0.78 & 0.5 & 0.81 & 1 & 0.61 & 0.7 \\
\hline $\mathrm{Pb}$ webs & $\mathbf{0 . 9}$ & 0.85 & 0.82 & 0.005 & 0.61 & 0.74 & $\mathbf{0 . 9}$ & $\mathbf{0 . 9 3}$ & 0.61 & 1 & $\mathbf{0 . 9 9}$ \\
\hline $\mathrm{Zn}$ webs & $\mathbf{0 . 9 7}$ & 0.83 & 0.8 & 0.1 & 0.7 & 0.8 & 0.87 & $\mathbf{0 . 9 5}$ & 0.7 & $\mathbf{0 . 9 9}$ & 1 \\
\hline
\end{tabular}


Correlation matrix for heavy metals in $\mathrm{PM}_{1}, \mathrm{PM}_{2.5}, \mathrm{PM}_{10}$, fractions of particulate matter and spider webs of $M$. silvestris in samples collected in 2012. Bold means the statistically significant values $(p<.050)$

\begin{tabular}{|c|c|c|c|c|c|c|c|c|c|c|c|}
\hline & $\begin{array}{c}\mathbf{P M}_{\mathbf{1}} \\
\mathbf{P b}\end{array}$ & $\begin{array}{c}\mathbf{P M}_{2.5} \\
\mathbf{P b}\end{array}$ & $\begin{array}{c}\mathbf{P M}_{10} \\
\mathbf{P b}\end{array}$ & $\mathbf{P M}_{\mathbf{1}} \mathbf{Z n}$ & $\begin{array}{c}\mathbf{P M}_{\mathbf{2 . 5}} \\
\mathbf{Z n}\end{array}$ & $\mathbf{P M}_{\mathbf{1 0}} \mathbf{Z n}$ & $\mathbf{P M}_{\mathbf{1}}$ & $\mathbf{P M}_{2.5}$ & $\mathbf{P M}_{\mathbf{1 0}}$ & $\begin{array}{c}\text { Pb } \\
\text { webs }\end{array}$ & $\begin{array}{c}\mathbf{Z n} \\
\text { webs }\end{array}$ \\
\hline $\mathrm{PM}_{1} \mathrm{~Pb}$ & 1 & 0.72 & 0.31 & $\mathbf{0 . 8 8}$ & 0.74 & 0.66 & $\mathbf{0 . 8 9}$ & $\mathbf{0 . 9 2}$ & 0.61 & $\mathbf{0 . 9 6}$ & $\mathbf{0 . 9 7}$ \\
\hline $\mathrm{PM}_{2.5} \mathrm{~Pb}$ & 0.72 & 1 & 0.52 & $\mathbf{0 . 9 4}$ & $\mathbf{0 . 9 9}$ & $\mathbf{0 . 9 8}$ & 0.54 & 0.84 & $\mathbf{0 . 9 7}$ & 0.68 & 0.76 \\
\hline $\mathrm{PM}_{10} \mathrm{~Pb}$ & 0.31 & 0.52 & 1 & 0.45 & 0.57 & 0.63 & 0.54 & 0.55 & 0.58 & 0.27 & 0.29 \\
\hline $\mathrm{PM}_{1} \mathrm{Zn}$ & $\mathbf{0 . 8 8}$ & $\mathbf{0 . 9 4}$ & 0.45 & 1 & $\mathbf{0 . 9 4}$ & $\mathbf{0 . 8 9}$ & 0.75 & $\mathbf{0 . 9 6}$ & $\mathbf{0 . 9}$ & $\mathbf{0 . 8 8}$ & $\mathbf{0 . 9 3}$ \\
\hline $\mathrm{PM}_{2.5} \mathrm{Zn}$ & 0.74 & $\mathbf{0 . 9 9}$ & 0.57 & $\mathbf{0 . 9 4}$ & 1 & $\mathbf{0 . 9 9}$ & 0.59 & 0.86 & $\mathbf{0 . 9 6}$ & 0.67 & 0.77 \\
\hline $\mathrm{PM}_{10} \mathrm{Zn}$ & 0.66 & $\mathbf{0 . 9 8}$ & 0.63 & $\mathbf{0 . 8 9}$ & $\mathbf{0 . 9 9}$ & 1 & 0.52 & 0.8 & $\mathbf{0 . 9 6}$ & 0.6 & 0.68 \\
\hline $\mathrm{PM}_{1}$ & $\mathbf{0 . 8 9}$ & 0.54 & 0.54 & 0.75 & 0.59 & 0.52 & 1 & $\mathbf{0 . 9}$ & 0.5 & $\mathbf{0 . 9}$ & 0.87 \\
\hline $\mathrm{PM}_{2.5}$ & $\mathbf{0 . 9 2}$ & 0.84 & 0.55 & $\mathbf{0 . 9 6}$ & 0.86 & 0.8 & $\mathbf{0 . 9}$ & 1 & 0.81 & $\mathbf{0 . 9 3}$ & $\mathbf{0 . 9 5}$ \\
\hline $\mathrm{PM}_{10}$ & 0.61 & $\mathbf{0 . 9 7}$ & 0.58 & $\mathbf{0 . 9}$ & $\mathbf{0 . 9 6}$ & $\mathbf{0 . 9 6}$ & 0.5 & 0.81 & 1 & 0.61 & 0.69 \\
\hline $\mathrm{Pb}$ webs & $\mathbf{0 . 9 6}$ & 0.68 & 0.27 & $\mathbf{0 . 8 8}$ & 0.67 & 0.6 & $\mathbf{0 . 9}$ & $\mathbf{0 . 9 3}$ & 0.61 & 1 & $\mathbf{0 . 9 9}$ \\
\hline $\mathrm{Zn}$ webs & $\mathbf{0 . 9 7}$ & 0.76 & 0.29 & $\mathbf{0 . 9 3}$ & 0.77 & 0.68 & 0.87 & $\mathbf{0 . 9 5}$ & 0.69 & $\mathbf{0 . 9 9}$ & 1 \\
\hline
\end{tabular}

A significant correlation among variables was discovered in the following cases: in the 2011: a strong positive correlation between $\mathrm{Pb}$ on the webs and $\mathrm{Pb}$ associated with $\mathrm{PM}_{1}$ (conventional measurement) and between average concentration of $\mathrm{Pb}$ on the webs and $\mathrm{PM}_{1}$ and $\mathrm{PM}_{2.5}$ mass (conventional measurement). Next, also in 2011, a strong positive correlation between concentrations of $\mathrm{Zn}$ on the webs and $\mathrm{Pb}$ associated with $\mathrm{PM}_{1}$ (classic measurement) and $\mathrm{Pb}$ content on webs was revealed, as well as the strong positive correlation between $\mathrm{Zn}$ content on webs and $\mathrm{PM}_{2.5}$ mass (conventional measurement). In the subsequent year 2012: the strong positive correlations were discovered for $\mathrm{Pb}$ concentrations on the webs and in $\mathrm{PM}_{1}$ and $\mathrm{PM}_{2.5}$ mass (conventional measurement) and among $\mathrm{Pb}$ concentrations on the webs and $\mathrm{Zn}$ concentration on the web and finally $\mathrm{Pb}$ concentrations on the webs were positively correlated with $\mathrm{Pb}$ and $\mathrm{Zn}$ associated with $\mathrm{PM}_{1}$ (classic measurement). Next, also in 2012 Zn concentrations on the webs were positively correlated with $\mathrm{Pb}$ and $\mathrm{Zn}$ associated with $\mathrm{PM}_{1}$ and with $\mathrm{PM}_{2.5}$ mass (classic measurement).

What is more, we employed one-way ANOVA for further analysis where the influence of one classifying factor, ie $\mathrm{PM}$ (with three levels: $\mathrm{PM}_{1} ; \mathrm{PM}_{2.5}$ and $\mathrm{PM}_{10}$ ) was studied (the mean values of $\mathrm{PM}$ mass and associated $\mathrm{Pb}$ and $\mathrm{Zn}$ expressed in $\left[\mu \mathrm{g} / \mathrm{m}^{3}\right]$ were changed into $[\mu \mathrm{g} / \mathrm{g}])$. The obtained significance level $p<0.05(p=0.04 ; F=2.96)$ for $\mathrm{Zn}$ and for $\mathrm{Pb}$ $(p=0.01 ; F=3.11)$ indicated the significant differences of the average concentrations of these elements in particulate matter of atmospheric aerosol measured with conventional method and webs. The graphical interpretation of conducted analysis presents Figure 2. The results of post-hoc tests confirmed the presence of significant differences among all concentrations PM-emission fractions and associated heavy metals and webs (Table 6). Results obtained with the use of webs and classic methods do not exhibit common features nor homogeneity.

Table 6

Results of post-hoc tests for $\mathrm{Pb}$ and $\mathrm{Zn}$ concentrations measured with conventional methods and webs $(p<.050)$. Bold means the statistically significant values

\begin{tabular}{|c|c|c|c|c|c|c|}
\hline Test & $\begin{array}{l}\mathrm{PM}_{1} \mathrm{~Pb}- \\
\mathrm{Pb} \text { webs }\end{array}$ & $\begin{array}{c}\mathrm{PM}_{2.5} \mathrm{~Pb}- \\
\mathrm{Pb} \text { webs }\end{array}$ & $\begin{array}{c}\mathrm{PM}_{10} \mathrm{~Pb}- \\
\mathrm{Pb} \text { webs }\end{array}$ & $\begin{array}{c}\mathrm{PM}_{1} \mathrm{Zn}- \\
\mathrm{Zn} \text { webs }\end{array}$ & $\begin{array}{c}\mathbf{P M}_{2.5} \mathrm{Zn} \text { - } \\
\text { Zn webs }\end{array}$ & $\begin{array}{c}\mathbf{P M}_{10} \mathrm{Zn}- \\
\mathrm{Zn} \text { webs }\end{array}$ \\
\hline Bonefe & 0.000 & 0.002 & 0.000 & 0.044 & 0.009 & 0.03 \\
\hline HSD Tukey & 0.001 & 0000 & 0.004 & 0.006 & 0.033 & 0.002 \\
\hline
\end{tabular}


a)

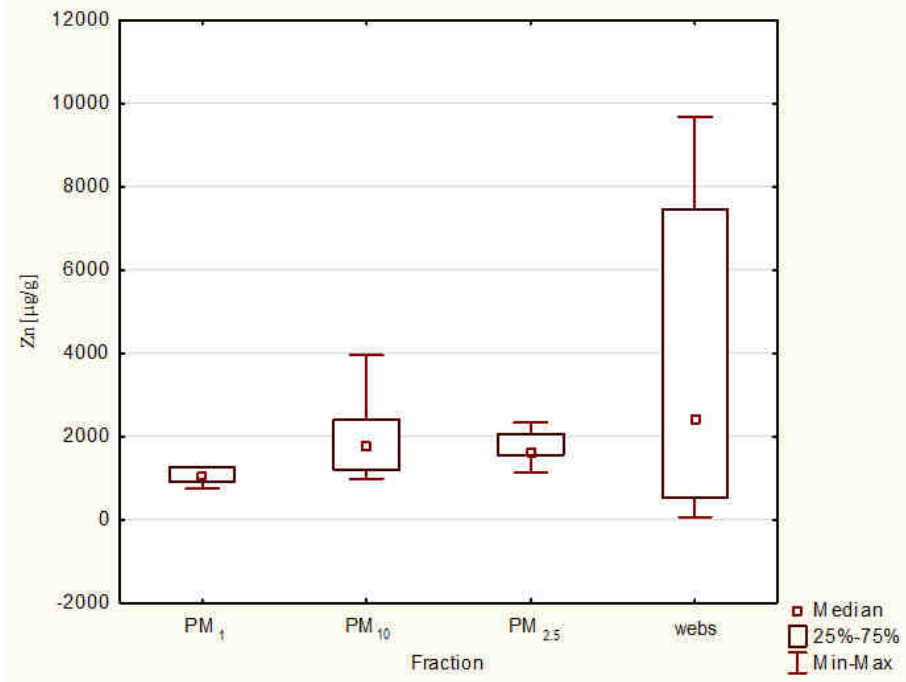

b)

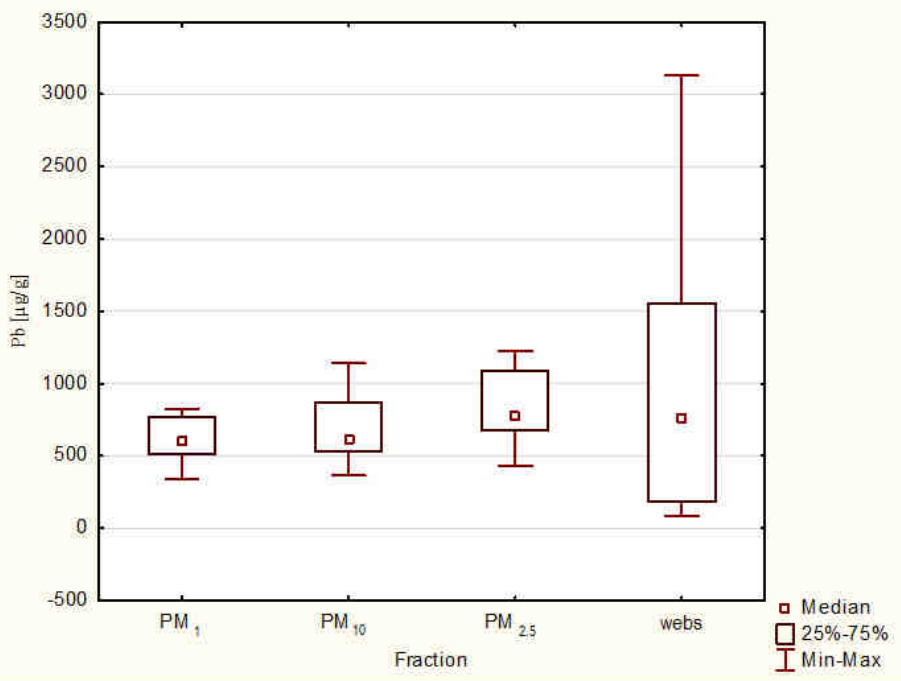

Fig. 2. Graphic interpretation of one-way ANOVA for $\mathrm{Zn}$ (a) and $\mathrm{Pb}$ (b). For ANOVA calculations mean concentrations of $\mathrm{PM}$ mass and associated $\mathrm{Pb}$ and $\mathrm{Zn}$ measured with conventional method in $\left[\mu \mathrm{g} / \mathrm{m}^{3}\right]$ were changed into $[\mu \mathrm{g} / \mathrm{g}]$

To summarize, it was showed that average concentrations of $\mathrm{Pb}$ and $\mathrm{Zn}$ on spider webs correspond only with the average concentrations of $\mathrm{Pb}$ and $\mathrm{Zn}$ associated with $\mathrm{PM}_{1}$ measured with classic method and reflect the concentrations of $\mathrm{PM}_{2.5}$ mass. Thus, our findings suggest the lack of significant correlation among all the studied parameters apart from some incidental cases. 


\section{Discussion}

The high concentrations of elements in the atmospheric aerosol such as $\mathrm{Zn}$ and $\mathrm{Pb}$ are often connected with the development of automotive industry in the urban area [14-16]. The emissions from the vehicles indicate the pollution deriving from the combustion system, as well as the mechanical usage of certain elements of car and road surface. Such elements as $\mathrm{Zn}, \mathrm{Cu}, \mathrm{Pb}, \mathrm{Cd}, \mathrm{Pt}, \mathrm{Fe}$ and $\mathrm{Cr}$ enter the atmosphere as a result of brake usage, catalytic converter activity and the detrition of tyres [17]. Zinc is also transmitted (altogether with $\mathrm{Ca})$ as a result of the engine oil usage, however $\mathrm{Mn}, \mathrm{Fe}$ and $\mathrm{Cu}$ derive from the petrol combustion ( $\mathrm{Mn}$ is added instead of $\mathrm{Pb}$ for increasing the octane number of fuel) [18].

The results obtained by the web sampling indicate the high level of pollution in samples collected from traffic-orientated sites 3, 4 and 5. A relatively high concentrations of zinc were revealed even at sites 1 and 2 (up to $407 \mu \mathrm{g} / \mathrm{g}$ ). Both sites were situated in a distance from the emission sources. In Hose's work [4] the maximum level of zinc was $800 \mu \mathrm{g} / \mathrm{g}$ for webs located near the high traffic road which were exposed from March to September. The obtained high concentrations of $\mathrm{Zn}$ for site 1 are probably caused by the immediate neighborhood of this area with the industrial slag heaps created in the period of functioning of smelter plant. Such conclusion is a result of the analysis of possible origin sources of heavy metals. The high concentrations of $\mathrm{Zn}$ for site 2, located in the eastern part of the city, are probably related with the dominance of south-western winds in Wroclaw.

The highest concentrations of heavy metals in 2011-2012 were recorded at sites 3, 4 and 5 for both: dust on webs and particulate matter of the atmospheric aerosol collected with the classic method. The strong positive correlations were recorded only between the concentrations of $\mathrm{Pb}$ and $\mathrm{Zn}$ on webs and trace metals associated with $\mathrm{PM}_{1}$ which is astonishing as fine pieces of solid or liquid matter could derive from long-range transport as usually they are able to overcome long distances from emission sources. The concentrations and size distributions of trace metals are governed by the nature of emissions to the atmosphere, as well as by rates of wet and dry depositions, clouds types, exchange of air between the boundary layer and free troposphere and chemical transformations. The trace metals are found in almost all atmospheric aerosol size fractions. Accumulation mode particles with diameter of $1 \mu \mathrm{m}$ and less deposit slowly and therefore are transported over long distances [19]. It suggests that pollutants identified on webs could probably reflect the pollution coming from the distant area.

The correlation was also recorded among the concentrations of $\mathrm{Pb}$ and $\mathrm{Zn}$ on webs and $\mathrm{PM}_{2.5}$ mass. Hose et al [4] measured the level of dust among three sites differing with the pollution level and compared the obtained results with the selected heavy metal contents identified on webs of two species of spiders (Badumna socialis and Stiphidion facetum) at the same sites. In the described studies the level of dust differed from the level of metals identified on webs [4].

We did not record any correlation among spider webs and $\mathrm{PM}_{1}$, which is surprising as this fraction of airborne particulate matter is always present in the close vicinity of emission sources. What is more, further statistical analyses revealed the lack of homogeneity among all data obtained with the classic methods and webs sampling.

To summarize, the existing strong positive correlations suggest rather incidental convergence not the real relationship. As further statistic calculations do not revealed homogeneity among heavy metals concentrations for all fractions of the airborne particulate 
matter and associated heavy metals and webs, we conclude the webs should be applied in the same way as the other biomonitors such as lichens, plants and mosses to evaluate air pollution level. It seems, that all Agelenidae webs, which are ubiquitous, are very suitable for the indication of pollutants, since representatives of this taxon are relatively easy identified and weave dense, extensive, easily recognizable webs and, most importantly, are active all-year-round, even in low temperatures [10]. Such method of indication is undoubtedly advantaged compared to the conventional methods of the estimation of air pollutants where a short-term information is usually available. The apparatus function often few days due to the high financial cost. What is more, the assessment cannot be conducted in randomly selected sites because of theft risk.

A deposition of pollutants on spiders webs is a separate issue, undoubtedly apart from the external way, one should consider also an internal way of the pollution penetration. The radioactive marking of web done in Araneidae representatives exhibiting the habit of old web eating revealed that as far as the $80 \%$ of the new construction consists of consumed old threads [10]. Since Malthonica silvestris does not exhibit such behavior the heavy metals deriving from the old webs and old depositions could not enter the new webs, although the victims being the prey of this species could derive from the larger area than inhabiting by spider alone which can directly affect the web composition. On the other hand, it was observed that washing the webs with diluted acid reduced metal concentrations up to $80 \%$ [4].

\section{Conclusions}

All studied dust deposited on webs as well as concentrations of airborne particulate matter measured with conventional method reflect the high content of $\mathrm{Zn}$ and $\mathrm{Pb}$ at traffic oriented sites 3, 4 and 5. It was found that average heavy metals concentrations on spider webs correlate with the average level of $\mathrm{Pb}$ and $\mathrm{Zn}$ concentrations associated with one fine fraction of atmospheric aerosol $\left(\mathrm{PM}_{1}\right)$ and reflect the concentrations of $\mathrm{PM}_{2.5}$ mass only. Results suggest that the content of $\mathrm{Zn}$ and $\mathrm{Pb}$ on webs does not generally reflects the content of these elements in dust present in the bioaerosol. No more correlation patterns were observed suggesting the further use of webs as bioindication tool in the same way as other bioindicators are applied. The use of spider webs is a very cost-efficient and often more reasonable than the use of such bioindicators as lichens or mosses (there are some exceptions like the possibility of the use of moss-bags regardless of the climatic conditions) because application of webs can be carried out all-year-round, is quick and easy-to-apply.

Studying the correlation between the content of heavy metals in the body of spider as well as in its molts and on its webs would give an important information about the available ways of pollution penetration.

\section{Acknowledgments}

The work was financed by Minister of Science and of Higher Education, research project no. N N305 096639.

\section{References}

[1] Orliński R. Chemosphere. 2002;48:181-186. DOI: 10.1016/S0045-6535(02)00062-0. 
[2] Ciesielczuk T, Olszowski T, Prokop M, Kłos A. Ecol Chem Eng S. 2012;19:585-595. DOI: 10.2478/v10216-011-0041-8.

[3] Zechmeister HG, Dullinger S, Hohenwallner D, Riss A, Hanus-Illnar A, Sharf S. Environ Sci Pollut R. 2006;13:398-405. DOI: 10.1065/espr2006.01.292.

[4] Hose GC, James JM, Gray MR. Environ Pollut. 2002;120:725-733.

[5] Rybak J, Sówka I, Zwoździak A. Environ Prot Eng. 2012;3:175-181. DOI: 10.5277/EPE120315.

[6] Rybak J. Olejniczak T. Environ Sci Pollut Res 2014;21:2313-24. DOI: 10.1007/s11356-013-2092-0.

[7] Xiao-Li S, Yu P, Hose GC, Jian C, Feng-Xiang L. Bul Environ Contam Toxicol. 2006;76(2):271-277. DOI: 10.1007/s00128-006-0917-y.

[8] Lissner J. The spiders of Europe and Greenland. 2011. http://jorgenlissner.dk/Agelenidae.aspx

[9] Champion de Crespigny FE, Herberstein ME, Elgar MA. Naturwissenschaften. 2001;88:42-45. DOI: $10.1007 / \mathrm{s} 001140000194$.

[10] Foelix RF. Biology of Spiders. New York: Oxford University Press; 2011.

[11] Nyffeller M, Moor H, Foelix RF. J Arachnol. 2001;29:119-124. DOI: 10.1636/0161-8202(2001)029[0119:SFOE]2.0.CO;2.

[12] Park JG, Moon MJ. Korean J Entomol. 2002;32(4):223-232. DOI: 10.1111/j.1748-5967.2002.tb00033.x.

[13] Report on environmental status in Lower Silesia province in 2011. WIOŚ (Provincional Environment Protection Inspectorate). Wrocław, WIOŚ; 2012.

[14] Laugh GC, Schauer, JJ, Park JS, Shafer MM., Deminter, JT, Weinstein, JP. Environ Sci Technol. 2005;39:826-836. DOI: 10.1021/es048715f.

[15] Gugamsetty B, Wei H, Liu Ch, Awasthi A, Hsu S, Tsai Ch, Roam G, Wu Y, Chen Ch. Aerosol Air Qual Res. 2012; 12: 476-491. DOI:10.4209/ aaqr.2012.04.0084.

[16] Sternbeck J, Sjodin A, Andreasson K, Atmos Environ. 2002;36:4735-4744. DOI: 10.1016/S1352-2310(02)00561-7.

[17] Amato F, Nava S, Lucarelli F, Querol X, Alastuey A, Baldasano JM, Pandolfi M. Sci Total Environ. 2010; 408:4309-4318. DOI:10.1016/j.scitotenv.2010.06.008.

[18] Moore K, Polidori A, Sioutas C. Toxicological assessment of particulate emissions from the exhaust of old and new heavy- and light-duty vehicules. METRANS Project 09-07, Final report, University of Southern California; 2011.http://www.metrans.org/sites/default/files/research-project/09-

07_Moore_METRANS_final_report_0_0.pdf.

[19] Samara C, Voutsa D. Chemosphere. 2005; 59:1197-1206. DOI: 10.1016/j.chemosphere.2004.11.061.

\title{
OCENA EFEKTYWNOŚCI SIECI PAJECCZYCH W MONITOROWANIU JAKOŚCI POWIETRZA ATMOSFERYCZNEGO
}

\author{
${ }^{1}$ Zakład Biologii i Ekologii, Politechnika Wrocławska \\ ${ }^{2}$ Zakład Ekologistyki, Politechnika Wrocławska \\ ${ }^{3}$ Crocker Nuclear Laboratory, University of California at Davis, USA
}

\begin{abstract}
Abstrakt: Celem badań była ocena efektywności sieci pajęczych jako narzędzia do indykacji zanieczyszczeń komunikacyjnych powietrza atmosferycznego. Wykorzystano sieci gatunku Malthonica silvestris (1. KOCH, 1872) należącego do rodziny Agelenidae. Pajęczyny oceniono pod kątem zawartości dwóch metali ciężkich (ołów i cynk) związanych $\mathrm{z}$ emisjami pochodzącymi z komunikacji drogowej. Otrzymane wyniki zestawiono z pomiarami wykonanymi metodami klasycznymi oceny jakości powietrza atmosferycznego (impaktory). Wysokie stężenia obydwu badanych metali odnotowano na trzech stanowiskach badawczych zlokalizowanych w miejscach o wysokim natężeniu ruchu kołowego we Wrocławiu, z kolei na obszarach o mniejszym natężeniu ruchu odnotowano niższe i statystycznie istotne wartości tych metali. Takie same wyniki otrzymano przy zastosowaniu obydwu metod (sieci pajęczych i metody klasycznej). Jednakże, silne pozytywne korelacje obserwowano jedynie w przypadku ołowiu i cynku związanych z frakcją pyłu drobnego $\mathrm{PM}_{1}$ i tych samych metali zidentyfikowanych na sieciach pajęczych. Stwierdzono także silną dodatnią korelację w przypadku stężeń $\mathrm{Zn} \mathrm{i} \mathrm{Pb}$ odnotowanych na sieciach pajęczych i frakcją pyły mierzonego metodą klasyczną $\mathrm{PM}_{2.5}$ (ale nie metalami!). Ponadto, nie zaobserwowano żadnych istotnych statystycznie korelacji między stężaniami metali i frakcjami pyłu mierzonymi obiema metodami. Co więcej, wyniki analizy wariancji wskazują na brak homogeniczności oraz istnienie różnic istotnych statystycznie między stężaniami metali zarejestrowanymi na sieciach i za pomocą metody klasycznej. Jako że stwierdzone korelacje można uznać za przypadkowe, nie rekomenduje się
\end{abstract}


wykorzystania sieci zamiennie z metodą klasyczną oceny jakości powietrza atmosferycznego. Jednakże, tak jak inne bioindykatory, sieci stanowią doskonałe narzędzie do monitoringu powietrza ze względu na łatwość poboru próbek, możliwość oceny zanieczyszczeń długoterminowych, dostępność. Brak zależności od światła i dostępność przez cały rok czyni je narzędziami znacznie bardziej przydatnymi do bioindykacji niż obecnie powszechnie wykorzystywane mchy, rośliny czy porosty.

Słowa kluczowe: sieci pajęcze, jakość powietrza, biomonitoring, metale ciężkie 